\section{Letters, Notes, and Answers}

All communications in regard to editorial business should be addressed to The EDITOR, British Medical Journal, B.M.A. House, Tavistock Square, W.C.1.

ORIGINAL ARTICLES and LETTERS forwarded for publication are understood to be offered to the British Medical Jcurnal alone unless the contrary be stated. Correspondents who wish notice to be taken of their communications should authenticate them with their names, not necessarily for publication.

their names, not necessarily for publication.
Authors desiring REPRINT of their articles published in the British Medical lournal must com of their articles published in the British Medical lournal must communicate with the Financial Secretary and Business Manager, British Medical Association House, Tavistock Square, W.C.1, on receipt of prools. Authors over-seas not sent abroad.

All communications with reference to ADVERTISEMENTS, as well as orders for copies of the Journal, should be addressed to the Financial Secretary and Business Manager.

The TELEPHONE NUMBER of the British Medical Association and the British Medical Journal is EUSTON 2111 (internal exchange, four lines)

The TELEGRAPHIC ADDRESSES are:

EDITOR OF THE BRITISH MEDICAL JOUR.VAL, Aitiology Vestcent, London.

FINANCIAL SECRETARY AND BUSINESS MANAGER (Advertisements, etc.), Articulate Weslcent, London. MEDICAL SECRETARY, Medisecra Westcent, London.

The address of the Irish Office of the British Medical Association is 18, Kildare Street, Dublin (telegrams: Bacillus, Dublin; telephone: 62550 Dublin), and of the Scottish ()fice, 7, Drumsheugh Gardens, Edinburgh (telegrams: Associate, Edinburgh ; telephone: 24361 Edinburgh)

\section{QUERIES AND ANSWERS}

The Pox Doctor's Clerk

Dr. Philip Gosse (Steyning) writes: The other day a friend of mine was out hunting, and four foxes were found in the small withy-bed, when a farm labourer exclaimed to the master: "As lucky as the pox doctor's clerk." Can any medical historian explain this surprising saying? What is a pox doctor, why had he a clerk, and why was he lucky?

\section{Callosities}

Dr. J. M. CRAIG (High IVycombe) writes: In reply to "Perplexed" (March 17th, p. 515), I would suggest that he tries a " Jones" bar nailed obliquely across the boot or shoe behind the heads of the great and little metatarsals. This will relieve the pressure on the callosities. The callosities can be softened by putting on a patch of elastoplast strapping. In my experience these callosities are prone to occur in elderly diabetics. This bar of leather should be one-half to three-quarters of an inch deep on the inside to one-quarter to one-eighth deep on the outside; and about three to four inches broad.

\section{Salary-"Economy Cuts"}

"CC. T.," whilst employed by the L.C.C., received a salary which was subject to "economy cuts." Is he liable on the nominal salary or the net amount received?

** On the net amount only.

\section{LETTERS, NOTES, ETC.}

\section{Greenstick Fracture at Age 27}

Dr. LeONARD BARber (Bristol Mental Hospital, Fishponds) writes: The following case may be of interest in view of the fact that Dr. R. Salisbury Voods has reported a similar case in a male, aged 21, in your issue of March 3rd. A man, aged $27^{\circ}$ years 10 months, while playing Association football in October last, fell on his hand with his arm extended. He complained of severe pain in his forearm and acute tenderness over the centre of the radius. $\mathrm{He}$ was unable to pronate or supinate his hand without a good deal of pain, and he had little or no grip. The forearm was considerably swollen and tense. In the absence of any evidence of a fracture a diagnosis of strained flexor tendons of the forearm was made. The condition was treated with lotio plumbi $\overline{\mathbf{c}}$ opio, firm bandaging, and massage at frequent intervals. The swelling quickly subsided and the pain became less acute, but pronation and supination of the hand was still painful and the grip weak. Three weeks after this accident the patient had the misfortune to have his injured arm jammed against a doorpost, the force of the blow being applied immediately over the site of the previous injury. Again there was no deformity or any symptoms to suggest a fracture, but it was deemed advisable to have an $x$-ray examination of his arm. The skiagram showed a greenstick fracture of the radius situated about the middle of the bone. There was a definite crack in the anterior surface of the radius extending about half-way through the bone, and here the bone had split longitudinally to the extent of a little over a quarter of an inch on either side of the base of the crack.

\section{Jubilee of the word "Tabloid"}

March 14 th was the fiftieth anniversary of the registration of "Tabloid " as a trade mark " "Tabloid" is a coined word, registered in 1884 by Burroughs Wellcome and Co., successors to Brockedon, who originated compressed medicaments in the form of biconvex disks under the designation of " compressed pills." Thirty lines are devoted to it in the Oxford English Dictionary. The ease with which the word "tabloid" comes to the tongue and the universal recognition of the high standard of quality of all products issued under this trade mark has entailed a very diligent guardianship of the owners' rights. 'Until 1903 the owners' exclusive right to the word remained unchallenged, but in that year a successful action against " passing off" was brought in the High Court of Justice. "Tabloid," as a result of these proceedings, was certified under Section 77a of the 'Trade Marks Act, 1883-8, and Burroughs Wellcome and $C o$. were awarded damages and costs. Time and again since then injunctions against infringement have been granted in courts of justice both in the British Empire and in the United States of America. Even a foreign pharmacopoeia has been required to publish a correction in regard to misuse of the word in the text.

\section{Definition of Terms}

"M.B.Oxon" writes: In the British Medical Journal of March 10th (p, 454), and in the previous week's issue (p. 401), various writers express conflicting views on menstruation and ovulation not always in very, decorous language. At the present time, when so much is written not only in professional papers but in the lay press about birth control, it is very confusing to find that there seems. to be no very great certainty about even the meaning. of such technical terms as "menstruation." It would be helpful if someone who can speak with authority on the subject were to summarize the present position, distinguishing what is generally admitted from what is speculative. As things are, many medical men must feel that the ground is slipping from under their feet.

\section{How to Expedite Settlement}

A correspondent in South India sends us a copy of a letter from an Indian doctor to the son of one of his patients. "I came across it," he says, "during some official correspondence and took a copy, as I thought it might be of interest to your readers." The letter runs as follows:

$$
\text { Dear Mr. }
$$

Ifrewith I enclose, as per your desire, my bill for having so far attended on your dear mother. She has passed through a very great crisis, and, at such an advanced age as hers, it is only by Cod's grace that she has been spared to us. Praying that she may enjoy a long lease of life,

I remain, yours sincerelv,

P.S.-I request that you will expedite the settlement of the bill as much as possible.

\section{Increased Intraocular Tension as a Cause of Severe Frontal Headache} A Correction

In a letter referring to his article on this subject, in the Journal of January 20 th, Flight Lieutenint R. L. Raymond points out that on page 103, col. 2 , line 8 , the sentence beginning "In this case . . " should read: "In this case note the previous unavailing course of salines and A.P.C., and the complete withholding of A.P.C. while in hospital." The point is emphasized that in Case 4 relief of increased intraocular tension was obtained by the use of eserine instillation alone.

\section{Vacancies}

Notifications of offices vacant in universities, medical colleges, and of vacant resident and other appointments at hospitals, will be found at pages 38, 39, 40, 41, 44, and 45 of our advertisement columns, and advertisements as to partnerships, assistantships, and locumtenencies at pages 42 and 43 .

A short summary of vacant posts notified in the advertisement columns appears in the Supplement at page 120. 